\title{
SEASONAL CHANGES IN THE OCCURRENCE OF LISTERIA MONOCYTOGENES IN DUHOK PROVINCE
}

\author{
Aazd M. T. Al-Brefkani ${ }^{a, *}$ and Ismaeil M. A. Mammani ${ }^{\mathrm{b}}$ \\ aCollege of Medicine, University of Duhok, Kurdistan region-Iraq- azad.tahir@dpu.edu.krd \\ ${ }^{b}$ College of Health Science, University of Duhok, Kurdistan region-Iraq- ismaeil.mohammed@uod.ac
}

Received: Nov. 2018 / Accepted: Dec., 2018 / Published: Mar., 2019

https://doi.org/10.25271/sjuoz.2019.7.1.549

\begin{abstract}
:
Listeria monocytogenes are Gram-positive bacilli cause listeriosis, associated with high rates of hospitalization and mortality. A total of 1362 samples were investigated included 647 clinical samples and 715 from food. This study investigated the differences in the seasonal occurrence of L. monocytogenes in Kurdistan region-Iraq. L. monocytogenes was found in 48 samples $(3.52 \%)$ out of 1362 samples. There were 7/642(1.09\%) human clinical samples diagnosed with cold and moderate weather (November, December 2016, and January, February, April 2017). While 41/715(5.73\%) of L. monocytogenes isolates were found among food samples, meat samples $(n=37)$ and dairy samples $(n=4)$. A total of $37 / 476(7.77 \%)$ of the L. monocytogenes isolates in meat samples were detected during warm weather (from July through October 2016). In addition, L. monocytogenes in dairy products was found to be by $4 / 239$ (1.68\%), were isolated during the moderate season (October, November 2016, and April, May 2017). The study found that the incidence of meat contamination by L. monocytogenes increase significantly during the warm season in comparison with other seasons. Furthermore, the cases of human Listeriosis caused correlated well with the seasonal levels of L. monocytogenes found in dairy products. A statistically significant difference in the occurrence of L. monocytogenes isolates and seasons were identified in this study $(\mathrm{P}$ value $=<0.05)$.
\end{abstract}

KEYWORDS: Listeria monocytogenes, Listeriosis, Seasonal Changes, Clinical Specimens.

\section{INTRODUTION}

Listeria monocytogenes is a gram positive, mesophilic, facultative anaerobic bacterium. It is implicated in numerous food poisoning cases and foodborne infection outbreaks. This bacterium is unique because of its high mortality rate $(20 \%-30 \%)$ (Mead et al., 2000). The majority (99\%) of listeriosis cases are assumed to be through consumption of contaminated food (Swaminathan and Gerner-Smidt, 2007). Immuno-comprised individuals, newborns, pregnant women and the elderly are especially vulnerable to Listeriosis due to $L$. monocytogenes infection (Farber and Peterkin, 1991). Listeriosis can appear as a moderate non-invasive gastrointestinal disease or invasive illness as meningitis or septicemia (Vázquez-Boland et al., 2001). Spontaneous third trimester abortions, encephalitis, meningitis and septicemia are the most severe clinical manifestations of invasive Listeriosis. The more common clinical manifestations of Listeriosis include mild influenza-like infection, occasionally combined with gastroenteritis (McLauchlin et al., 2004). Up to date, 17 species related to genus Listeria have been established which includes: $L$. monocytogenes, L. ivanovii, L. seeligeri, L. innocua, $L$. welshimeri, L. grayi, L. marthii, L. rocourtiae, L. fleischmannii, $L$. weihenstephanensis, and those recently added L. floridensis, L. aquatica, L. cornellensis, L. riparia, L. grandensis, L. booriae, and L. newyorkensis (Weller et al., 2015). Listeria monocytogenes was confirmed as a primarily pathogenic to human and causing listeriosis. Whilst, L. ivanovii and L. seeligeri have also been associated with human infection in very rare cases (Guillet et al., 2010; Poulsen and Czuprynski, 2013). Seasonal distribution of this bacterium is a great concern and have been documented by numerous researchers (Jones et al., 1990; Strauch, 1991; MacGowan et al., 1994; Hitchens, 1995; Dumontet et al., 1997) . The study is aimed to investigate the seasonal variations in the occurrence of $L$. monocytogenes in
Duhok province-Kurdistan region. Seasons are defined as follows: Warm season occurs in the months of (June, July, August, and September); the moderate season is in the months of (October, March, April, and May); while cold season happens in (November, December, January, and February).

\section{MATERIALS AND METHODES}

\subsection{Sample Source}

A total of 1362 samples comprising of patient derived $(n=647)$ and food derived $(n=715)$ samples were evaluated in the present study. Clinical samples included pregnant women who have had the history of obstetrical complications (200 High vaginal swabs and 200 Urine samples), and blood samples were collected from 247 immuno-compromised patients whose ages ranged from 1 day to 85 years old. These immune-compromised patients suffered from different clinical problems; 101 with renal failure patients, 83 septicemia cases, 44 premature infants, 15 meningitis cases, and finally 4 heart failure cases were included in this analysis. On the other hand, 715 food samples were investigated in this study. Among them, 476 were meat samples; 309 chicken meat and 167 red meat. While, 239 samples were dairy products. Among them, 118 samples were from locally produced sheep raw milk and 121 samples were from locally prepared white soft cheese. Samples were taken at random during each season.

\subsection{Bacteriological Isolation}

This bacterium was isolated according to the procedure described by ISO 11290-1:1997 (Aznar and Solis, 2006). Double enrichment broth (Half Fraser \& Fraser) in addition to Harlequin ${ }^{\mathrm{TM}}$ Listeria Chromogenic agar was used to differentiate L. monocytogenes from other Listeria spp.

\subsection{Biochemical Tests}

Microgen Listeria-ID microwell test strip which contains 11 dried carbohydrate substrates which recommended in

* Corresponding author

This is an open access under a CC BY-NC-SA 4.0 license (https://creativecommons.org/licenses/by-nc-sa/4.0/) 
international standard methods (Hitchins, 2003) and the hemolysin reaction were performed in well number 12 (Dominguez Rodriguez et al., 1986).

\subsection{Molecular Investigation}

Isolation of genomic DNA from bacterial colonies was carried out using the boiling method according to the protocol described by (Adzitey et al., 2013; Dashti et al., 2009). 16S rRNA gene primer was described by (Park et al., 2016). The amplification reactions were accomplished in $25 \mu \mathrm{l}$ volume and 100 bp DNA ladder (GeNet Bio, South Korea) was used as a size marker (M) in all gels. The amplified DNA bands were separated by using agarose gel electrophoresis as designated by (Park et al., 2016).

\subsection{Statistical Analysis}

Chi-Square Analysis was used to show the significant differences among different seasons in the occurrence of $L$. monocytogenes.

\section{RESULTS}

The first molecular diagnostic step to confirm $L$. monocytogenes isolates was targeting the preserved regions of this bacterium 16SrRNA gene (Figure 1).

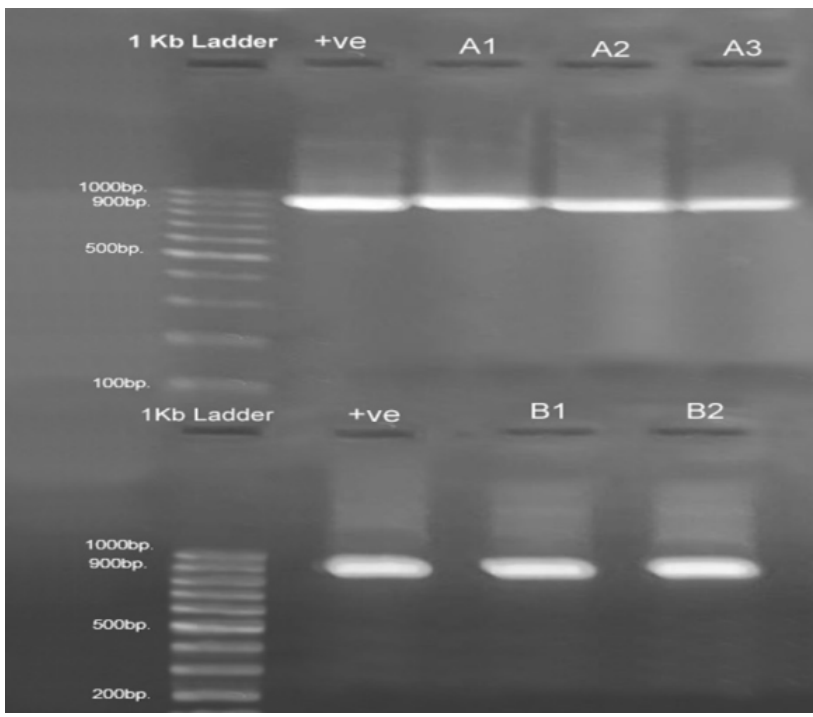

Figure 1: An example of 16SrRNA positive gene of $L$. monocytogenes isolated from food sources and clinical cases.

$1 \mathrm{~kb}$ molecular weight ladder was used in this PCR reaction. Lane 2 is positive control, (A1-A3) are 16SrRNA (938bp) positive gene of L. monocytogenes isolated from food sources. (B1-B2) are 16SrRNA positive gene of $L$. monocytogenes isolated from clinical cases.

The seasonal occurrence of L. monocytogenes isolates from food and clinical samples were analyzed in this study. $L$. monocytogenes was found in 48/1362 (3.52\%) of samples. the vast majority of positive samples were diagnosed during warm weather $30 / 48(62.50 \%)$. During the moderate season, $11 / 48$ $(22.92 \%)$ of the samples were found to be contaminated with $L$. monocytogenes., while only $7 / 48(14.58 \%)$ of positive samples were detected in cold season. A significant correlation was detected between isolated L. monocytogenes and seasons ( $\mathrm{P}$ value $=0.00001)($ Table 1, Figure 2).
Table 1: Listeria monocytogenes isolates derived from food and patient sources during cold, moderate and warm seasons

\begin{tabular}{|l|l|l|l|l|}
\hline Sample & $\begin{array}{l}\text { Listeria } \\
\text { isolated } \\
\text { from Meat } \\
\text { Products }\end{array}$ & $\begin{array}{l}\text { Listeria } \\
\text { isolated } \\
\text { from } \\
\text { Dairy } \\
\text { Products }\end{array}$ & $\begin{array}{l}\text { Listeria } \\
\text { isolated } \\
\text { from } \\
\text { Patients }\end{array}$ & $\begin{array}{l}\text { Total } \\
\text { Isolates }\end{array}$ \\
\hline $\begin{array}{l}\text { Cold } \\
\text { Season }\end{array}$ & $0(0.0 \%)$ & $2(4.17 \%)$ & $5(10.41 \%)$ & $7(14.58 \%)$ \\
\hline $\begin{array}{l}\text { Moderate } \\
\text { Season }\end{array}$ & $7(14.58 \%)$ & $2(4.17 \%)$ & $2(4.17 \%)$ & $11(22.92 \%)$ \\
\hline $\begin{array}{l}\text { Warm } \\
\text { Season }\end{array}$ & $30(62.5 \%)$ & $0(0.0 \%)$ & $0(0.0 \%)$ & $30(62.50 \%)$ \\
\hline Total & $37(77.08 \%)$ & $4(8.34 \%)$ & $7(14.58 \%)$ & $48(100 \%)$ \\
\hline
\end{tabular}

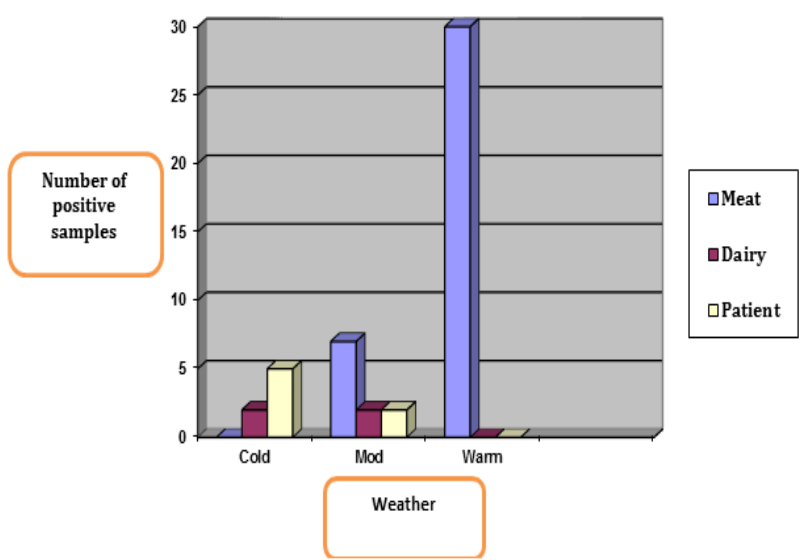

Figure 2: Shows Listeria monocytogenes isolated from food and patient sources during cold, moderate and warm seasons

\subsection{Pregnant Women}

The highest incidence of Listeriosis that occurred among pregnant women was seen during the November 2/82(2.43\%), By contrast, during the months December and January there were fewer cases of Listeriosis, by $1 / 154(0.64 \%)$ and $1 / 113(0.88 \%)$ respectively. No positive samples were detected in May and June. There wasn't statistically significant difference in the occurrence of cases of Listeriosis among pregnant women during the aforementioned months $(\mathrm{P}$-value $=0.31)($ Table 2$)$.

Table 2: Distribution of listeriosis cases among pregnant women according to seasons.

\begin{tabular}{|c|c|c|c|}
\hline $\begin{array}{r}\text { No., \% of } \\
\text { samples }\end{array}$ & $\begin{array}{c}\text { Positive (No. } \\
\& \%)\end{array}$ & $\begin{array}{c}\text { Negative (No. } \\
\& \%)\end{array}$ & Total \\
\hline Mate & $0(0.0 \%)$ & $26(100 \%)$ & 26 \\
\hline $\begin{array}{c}\text { June- } 2016 \\
\text { November- } \\
2016\end{array}$ & $2(2.43 \%)$ & $80(97.57 \%)$ & 82 \\
\hline $\begin{array}{c}\text { December- } \\
2016\end{array}$ & $1(0.64 \%)$ & $153(99.36 \%)$ & 154 \\
\hline $\begin{array}{c}\text { January-2017 } \\
\text { Total }\end{array}$ & $4(0.88 \%)$ & $112(99.12 \%)$ & 113 \\
\hline \multicolumn{2}{|c|}{$4(1.0 \%)$} & $396(99.00 \%)$ & $\begin{array}{c}400 \\
(100 \%)\end{array}$ \\
\hline
\end{tabular}

\subsection{Other Immunocompromised Patients}

Regards other immunocompromised patients (Renal failures, septicemia, premature infants and meningitis patients) dispersal of Listeriosis cases regarding the seasons is shown in (Table 3). Out of three positive cases, 1/19(5.26\%) was found in February 
2017, whereas the other $2 / 130(1.53 \%)$ cases were diagnosed in April-2017. No significant correlation was found between seasons and Listeria cases (P-value $=0.31),($ Table 3$)$.

Table 3: Distribution of Listeriosis cases among ImmunoCompromised individuals according to seasons.

\begin{tabular}{|c|c|c|c|}
\hline Date & $\begin{array}{c}\text { Positive } \\
(\text { No. \& } \\
\%)\end{array}$ & $\begin{array}{c}\text { Negative } \\
\text { (No. \& \%) }\end{array}$ & Total \\
\hline January-2017 & $0(0.0 \%)$ & $18(100 \%)$ & 18 \\
\hline February-2017 & $1(5.26 \%)$ & $18(94.74 \%)$ & 19 \\
\hline March-2017 & $0(0.0 \%)$ & $39(100 \%)$ & 39 \\
\hline April-2017 & $2(1.53 \%)$ & $128(98.47)$ & 130 \\
\hline June-2017 & $0(0.0 \%)$ & $41(100 \%)$ & 41 \\
\hline Total & $3(1.21 \%)$ & $244(98.79 \%)$ & 247 \\
\hline
\end{tabular}

\subsection{Meat}

The highest rate of $L$. monocytogenes isolates was detected during August 2016 27/208 (12.98\%). In addition, 2.77\%, 3.23\%, and $5.83 \%$ of isolates were demonstrated during July, September, and October respectively. There statistically significant relationship was found between the date of isolation and $L$. monocytogenes contamination in meat products $(\mathrm{P}-\mathrm{value}=$ 0.00079), (Table 4).

Table 4: Distribution of Listeria monocytogenes contamination among meat products according to the season of isolation.

\begin{tabular}{|c|c|c|c|}
\hline Date & $\begin{array}{c}\text { Positive (No. } \\
\& \%)\end{array}$ & $\begin{array}{c}\text { Negative (No. } \\
\& \%)\end{array}$ & Total \\
\hline July-2016 & $1(2.77 \%)$ & $35(97.23 \%)$ & 36 \\
\hline August-2016 & $27(12.98 \%)$ & $181(87.02 \%)$ & 208 \\
\hline September-2016 & $2(3.23 \%)$ & $60(96.77 \%)$ & 62 \\
\hline October-2016 & $7(5.83 \%)$ & $113(94.17 \%)$ & 120 \\
\hline November-2016 & $0(0.0 \%)$ & $50(100 \%)$ & 50 \\
\hline Total & $37(7.7 \%)$ & $439(2.23 \%)$ & 476 \\
\hline
\end{tabular}

\subsection{Dairy Products}

The sampling was started on $31^{\text {st }}$ July 2016 and terminated on 10th-MAY-2017. No isolates of L. monocytogenes were obtained during the months of July and August 2016 (Table 5). A single isolate of L. monocytogenes was isolated in October and in November 2016. A single isolate of L. monocytogenes was isolated in April and May 2017. A statistically significant relationship was observed between $L$. monocytogenes contamination and month of sampling $(\mathrm{P}$-value $=0.0076)$.
Table 5: Distribution of Listeria monocytogenes contamination according to date of sampling among dairy products

\begin{tabular}{|c|c|c|c|}
\hline Date & $\begin{array}{c}\text { Positive (No. } \\
\& \%)\end{array}$ & $\begin{array}{c}\text { Negative (No. } \\
\& \%)\end{array}$ & $\begin{array}{c}\text { Total } \\
\text { examined } \\
\text { samples }\end{array}$ \\
\hline JUL-2016 & $0(0.00 \%)$ & $3(100 \%)$ & 3 \\
\hline AUG-2016 & $0(0.00 \%)$ & $1(100 \%)$ & 1 \\
\hline OCT-2016 & $1(4.76 \%)$ & $20(95.24 \%)$ & 21 \\
\hline NOV-2016 & $1(11.11 \%)$ & $8(88.89 \%)$ & 9 \\
\hline APR-2017 & $1(1.00 \%)$ & $99(99.00 \%)$ & 100 \\
\hline MAY-2017 & $1(0.95 \%)$ & $104(99.05 \%)$ & 105 \\
\hline Total & $4(1.68 \%)$ & $235(98.32 \%)$ & 239 \\
\hline
\end{tabular}

\section{DISCUSSION}

This investigation looked at the Seasonal distribution of $L$. monocytogenes in Duhok province. The seasonal differences of $L$. monocytogenes in Kurdistan region have not been previously reported. Cases involving human Listeriosis occurred during cold weather and during the natural grazing season. The results obtained in our study differed from those obtained by the European Food Safety Authority study (EFSA, 2015). The EFSA study reported that human Listeriosis increased slightly during the warm season as compared with the other seasons of the year (Authority and Control, 2016). In addition, A study carried out in the United States obtained results that were disagree to those obtained in our study, where the vast majority of listeriosis cases were detected during August and September (Voetsch et al., 2007). The differing results obtained in this investigation could be due to differences in sample size variation and differentiation of the temperature between countries. In the present study, an increased number of contaminated meats with Listeria contamination were obtained during warm weather. An elevated percentage (12.98\%) was detected in August. Our results are similar to the findings of other earlier investigations (Rhoades et al., 2009; Elmali et al., 2015; Alewy et al., 2016). Earlier investigations failed to detect a seasonal pattern of $L$. monocytogenes conducted by (Wilson, 1995; GOMBAS et al., 2003). Regarding dairy products, a statistical significant relationship between L.monocytogenes isolates and the season of isolation were detected $(\mathrm{P}$ value $=0.0076)$, this study found that contamination with $L$. monocytogenes is more prevalent in two seasons only. Of four positive samples of $L$. monocytogenes that were isolated, 2 were isolated in spring and 2 in winter. Perhaps the unequal distribution of L. monocytogenes can be linked to: a) quality of feed given to animals, and b) variations in the global environment. Silage is commonly used by the Kurdish Farmer as animal feed. The percentage of contamination of silage with $L$. monocytogenes can be linked to how the silage is stored and the procedures used to prepare the silage. The rate of $L$. monocytogenes contaminated was probably due to the high rate of silage feeding in that season (Boerlin et al., 2003). The study of Boerlin proved that poor quality of silage is the main reason for an elevated incidence of listeriosis infections among ruminants. The lower incidence of contamination with $L$. monocytogenes in summer and in spring is most probably due to the animals grazing out in the fields on natural feed sources rather than silage (Fenlon et al., 1996). The high rate of raw milk contaminated with $L$. monocytogenes in winter season was confirmed by an earlier study (Meyer-Broseta et al., 2003). In conclusion, the study found that the incidence of meat 
contamination by L. monocytogenes increase significantly during the warm season in comparison with other seasons. Furthermore, the cases of human Listeriosis caused correlated well with the seasonal levels of L. monocytogenes found in dairy products. A statistically significant difference in the occurrence of $L$. monocytogenes isolates and seasons were identified in this study $(\mathrm{P}$ value $=<0.05)$

\section{REFERENCES}

Adzitey, F., Rahmat Ali, G.R., Huda, N., Cogan, T. and Corry, J. (2013), "Prevalence, antibiotic resistance and genetic diversity of Listeria monocytogenes isolated from ducks, their rearing and processing environments in Penang, Malaysia", Food Control, Elsevier B.V., Vol. 32 No. 2, pp. 607-614.

Alewy, D., Ba-salamah, H.A., Shater, A.-R., Sanabani, A.S. Al, Abd, F.M. and Galil, A. (2016), "Prevalence of Listeria monocytogenes in Red Meat in Dhamar Governorate / Yemen", Vol. 2 No. 12, pp. 73-78.

Authority, E.F.S. and Control, E.C. for D.P. and. (2016), “The European Union summary report on trends and sources of zoonoses, zoonotic agents and food-borne outbreaks in 2015", EFSA Journal, Wiley Online Library, Vol. 14 No. 12, p. e04634.

Aznar, R. and Solis, I. (2006), "PCR detection of Listeria monocytogenes in different food products compared with the mini-VIDAS LMO system and the standard procedure ISO 11290-1", Journal Für Verbraucherschutz Und Lebensmittelsicherheit, Springer, Vol. 1 No. 2, pp. 115-120.

Boerlin, P., Boerlin-Petzold, F. and Jemmi, T. (2003), "Use of listeriolysin $\mathrm{O}$ and internalin $\mathrm{A}$ in a seroepidemiological study of listeriosis in Swiss dairy cows", Journal of Clinical Microbiology, Vol. 41 No. 3, pp. 1055-1061.

Camargo, A.C., Woodward, J.J. and Nero, L.A. (2016), “The continuous challenge of characterizing the foodborne pathogen Listeria monocytogenes", Foodborne Pathogens and Disease, Mary Ann Liebert, Inc. 140 Huguenot Street, 3rd Floor New Rochelle, NY 10801 USA, Vol. 13 No. 8, pp. 405-416.

Chen, J.-Q., Regan, P., Laksanalamai, P., Healey, S. and Hu, Z. (2017), "Prevalence and methodologies for detection, characterization and subtyping of Listeria monocytogenes and L. ivanovii in foods and environmental sources", Food Science and Human Wellness, Elsevier, Vol. 6 No. 3, pp. 97-120.

Dashti, A.A., Jadaon, M.M., Abdulsamad, A.M. and Dashti, H.M. (2009), "Heat treatment of bacteria: A simple method of DNA extraction for molecular techniques", Kuwait Med J, Vol. 41 No. 2, pp. 117122.

Dominguez Rodriguez, L., Vazquez Boland, J.A., Fernandez Garayzabal, J.F., Echalecu Tranchant, P., Gomez-Lucia, E., Rodriguez Ferri, E.F. and Suarez Fernandez, G. (1986), "Microplate technique to determine hemolytic activity for routine typing of Listeria strains", Journal of Clinical Microbiology, Vol. 24 No. 1, pp. 99103

Doumith, M., Buchrieser, C., Glaser, P., Jacquet, C. and Martin, P. (2004), "Differentiation of the Major Listeria monocytogenes Serovars by Multiplex PCR", Vol. 42 No. 8, pp. 3819-3822.

Dumontet, S., Dinel, A. and Baloda, S. (1997), "Pathogen reduction in biosolids by composting and other biological treatments: A literature review", International Congress, Maratea, Vol. 1, pp. 251-295.

EFSA, E. (2015), "European Food Safety Authority and European Centre for Disease Prevention and Control", EFSA J, Vol. 13, p. 4329.

Elmali, M., CAN, H.Y. and Yaman, H. (2015), "Prevalence of Listeria monocytogenes in poultry meat", Food Science and Technology, SciELO Brasil, Vol. 35 No. 4, pp. 672-675.

Farber, J.M. and Peterkin, P.I. (1991), "Listeria monocytogenes, a food- borne pathogen.”, Microbiological Reviews, Am Soc Microbiol, Vol. 55 No. 3, pp. $476-511$.

Fenlon, D.R., Wilson, J. and Donachie, W. (1996), "The incidence and level of Listeria monocytogenes contamination of food sources at primary production and initial processing", Journal of Applied Bacteriology, Wiley Online Library, Vol. 81 No. 6, pp. 641-650.

GOMBAS, D.E., CHEN, Y., CLAVERO, R.S. and SCOTT, V.N. (2003), "Survey of Listeria monocytogenes in Ready-to-Eat Foods", Journal of Food Protection, Vol. 66 No. 4, pp. 559-569.

Guillet, C., Join-Lambert, O., Le Monnier, A., Leclercq, A., Mechaï, F., Mamzer-Bruneel, M.-F., Bielecka, M.K., et al. (2010), "Human listeriosis caused by Listeria ivanovii", Emerging Infectious Diseases, Centers for Disease Control and Prevention, Vol. 16 No. 1, p. 136.

Hitchens, A.D. (1995), "Listeria monocytogenes, p. 10.1-10.13", FDA Bacteriological Analytical Manual, 8th Ed. AOAC International, Arlington, $\mathrm{Va}$.

Hitchins, A.D. (2003), "Detection and enumeration of Listeria monocytogenes in foods", Bacteriological Analytical Manual, US Food \& Drug Administration, Center for Food Safety \& Applied Nutrition, Vol. 10.

Jones, K., Betaieb, M. and Telford, D.R. (1990), "Seasonal variation of thermophilic campylobacters in sewage sludge", Journal of Applied Bacteriology, Wiley Online Library, Vol. 69 No. 2, pp. 185-189.

Lee, S., Ward, T.J., Graves, L.M., Wolf, L.A., Sperry, K., Siletzky, R.M. and Kathariou, S. (2012), "Atypical Listeria Monocytogenes serotype $4 \mathrm{~b}$ strains harboring a lineage II-specific gene cassette", Applied and Environmental Microbiology, Vol. 78 No. 3, pp. 660-667.

Liu, D. (2008), Handbook of Listeria Monocytogenes, CRC press.

Liu, D., Lawrence, M.L., Gorski, L., Mandrell, R.E., Ainsworth, A.J. and Austin, F.W. (2006), "Listeria monocytogenes serotype 4b strains belonging to lineages I and III possess distinct molecular features", Journal of Clinical Microbiology, Vol. 44 No. 1, pp. 214-217.

Lomonaco, S., Nucera, D. and Filipello, V. (2015), "The evolution and epidemiology of Listeria monocytogenes in Europe and the United States", Infection, Genetics and Evolution, Elsevier, Vol. 35, pp. 172-183.

MacGowan, A.P., Bowker, K., McLauchlin, J., Bennett, P.M. and Reeves, D.S. (1994), "The occurrence and seasonal changes in the isolation of Listeria spp. in shop bought food stuffs, human faeces, sewage and soil from urban sources", International Journal of Food Microbiology, Elsevier, Vol. 21 No. 4, pp. 325334.

McLauchlin, J., Mitchell, Rt., Smerdon, W.J. and Jewell, K. (2004), "Listeria monocytogenes and listeriosis: a review of hazard characterisation for use in microbiological risk assessment of foods", International Journal of Food Microbiology, Elsevier, Vol. 92 No. 1, pp. 15-33.

Mead, P.S., Slutsker, L., Dietz, V., McCaig, L.F., Bresee, J.S., Shapiro, C., Griffin, P.M., et al. (2000), "Food-related illness and death in the United States", Journal of Environmental Health, National Environmental Health Association, Vol. 62 No. 7, p. 9.

Meyer-Broseta, S., Diot, A., Bastian, S., Rivière, J. and Cerf, O. (2003), "Estimation of low bacterial concentration: Listeria monocytogenes in raw milk", International Journal of Food Microbiology, Elsevier, Vol. 80 No. 1, pp. 1-15.

Orsi, R.H., den Bakker, H.C. and Wiedmann, M. (2011), "Listeria monocytogenes lineages: genomics, evolution, ecology, and phenotypic characteristics", International Journal of Medical Microbiology, Elsevier, Vol. 301 No. 2, pp. 79-96.

Park, S., Jung, H., Lee, M., Choi, H., Kim, J., Jung, J., Park, S., et al. (2016), "Detection of Listeria monocytogenes in Foods and Characterization by PFGE", Advances in Microbiology, Vol. 06 No. 04, pp. 343-349. 
Pérez-Trallero, E., Zigorraga, C., Artieda, J., Alkorta, M. and Marimón, J.M. (2014), "Two outbreaks of listeria monocytogenes infection, Northern Spain", Emerging Infectious Diseases, Vol. 20 No. 12, pp. 2155-2157.

Poulsen, K.P. and Czuprynski, C.J. (2013), "Pathogenesis of listeriosis during pregnancy", Animal Health Research Reviews, Cambridge University Press, Vol. 14 No. 1, pp. 30-39.

Rhoades, J.R., Duffy, G. and Koutsoumanis, K. (2009), "Prevalence and concentration of verocytotoxigenic Escherichia coli, Salmonella enterica and Listeria monocytogenes in the beef production chain: a review", Food Microbiology, Elsevier, Vol. 26 No. 4, pp. 357376

Strauch, D. (1991), "Survival of pathogenic microorganisms and parasites in excreta, manure and sewage sludge", Revue Scientifique et Technique (International Office of Epizootics), Vol. 10 No. 3, pp. 813-846.

Swaminathan, B. and Gerner-Smidt, P. (2007), "The epidemiology of human listeriosis", Microbes and Infection, Elsevier, Vol. 9 No. 10, pp. 1236-1243.

Vázquez-Boland, J.A., Kuhn, M., Berche, P., Chakraborty, T.,
Domínguez-Bernal, G., Goebel, W., González-Zorn, B., et al. (2001), "Listeria pathogenesis and molecular virulence determinants", Clinical Microbiology Reviews, Am Soc Microbiol, Vol. 14 No. 3, pp. 584-640.

Voetsch, A.C., Angulo, F.J., Jones, T.F., Moore, M.R., Nadon, C., McCarthy, P., Shiferaw, B., et al. (2007), "Reduction in the incidence of invasive listeriosis in foodborne diseases active surveillance network sites, 1996-2003”, Clinical Infectious Diseases, The University of Chicago Press, Vol. 44 No. 4, pp. 513-520.

Weller, D., Andrus, A., Wiedmann, M. and den Bakker, H.C. (2015), "Listeria booriae sp. nov. and Listeria newyorkensis sp. nov. from food processing environments in the USA", International Journal of Systematic and Evolutionary Microbiology, Vol. 65 No. 1, pp. 286-292.

Wilson, I.G. (1995), "Occurrence of Listeria species in ready to eat foods", Epidemiology and Infection, Vol. 115 No. 3, pp. 519-526. 